\title{
The Innovation of Ideological and Political Education in Colleges and Universities from the Perspective of Psychology
}

\author{
Shiliang Xu \\ Liaoning railway Vocanical and Technical College, Jinzhou, 121000, China \\ xushiliang875687@tom.com
}

Key words: positive psychology; college students; ideological and political education

\begin{abstract}
Now a growing number of colleges and universities continue to pay more attention to the ideological education of the students, some colleges cleverly use psychology to develop students' ideological education and have achieved good results. These colleges mainly use positive psychology to stimulate students' positive emotions to help them accept and digest the ideological education. In order to understand the feasibility and effect of the ideological education of positive psychology, this paper studies the methods and effects of college students' ideological education from the perspective of positive psychology.
\end{abstract}

\section{Introduction}

Positive psychology is one of major discoveries about psychological study. Since the date of being proposed, it has brought people incredible benefits through the changing research perspective of psychology and the restudy of the previous psychology. More than $90 \%$ of the previous psychology studies are about anxiety, depression and other negative emotions and less than $10 \%$ of the research works mentioned the topics of happy and joyfulness but without in-depth study. In fact, the earliest positive psychology study was proposed by Terman, who did related study and made some speeches in 1930s. Later, Abraham Maslow,the American social psychologist, published "A theory of human motivation" ,the book about psychology in 1943 to make more people realize the positive psychology, but did not come into a definite conclusion. Until the end of the 1990s, some people did in-depth studies on positive psychology and published correlative papers, which brings the positive psychology into the public eye. Later it developed into a subject specializing in the study of positive psychology. Now, positive psychology is applied into management, education and many other fields and have achieved good results, so the idea of applying it into the ideological education of college students has also been initiated.

\section{Overview about Positive Psychology}

The psychology study started relatively early that the discipline of psychology was established in the 1980s, however, positive psychology study was relatively late that it has been proposed until the end of the last century and after a long time, the related professional discipline.was finally established. There has been no accurate description about to positive psychology, some psychologists believe that positive psychology could explore the positive emotions and the behavior of these emotions with the scientific method and they also made detailed explanations on it. The details are as follows:

(1) Subjective Level: Positive Emotion and Experience

Positive emotions and experiences are the breakthrough point of positive psychology study. General positive emotions are happy, joyfulness, pride and satisfaction which could not only give people the psychological pleasure but also physical health. Generally speaking, people with a positive mood have a better physical condition than those with a negative one. Besides, positive psychology could also affect people's thinking. For example, the person with a positive mood could have more active and broader thinking than usual and could solve the problem which he can not deal with without that mood, sometimes could even have some novel bold ideas. What's more, positive emotions can help people get rid of the impacts of negative emotional. For example, when 
people encounter some unhappy things, they would inevitably be depressed, but if we could take some positive measures to improve people's positive emotions, then they might temporarily forget the troubles and find the answer in a positive mood suddenly to help themselves relieve. Last but not least, Positive emotions could help people enhance psychology bearing capacity, and accept and integrate into changing word and new environment more rapidly.

(2) Personal Level: the Positive Personality Characteristics

The personality refers to the most frequent and prominent mental state and behavior showed in people's daily life and the positive personality characteristic means the excellent mental state and behavior. There are two criterion to determine whether a person's personality is positive. First criterion is the perception and the judgment of himself. Generally speaking ,those who usually have a positive attitude of self - understanding and life experience are full of passion to life, business or something they love and have the ability to live independently, adapt to the changing environment and have the courage to accept the challenge from themselves and others. Second criterion is the attitude of the relationship with others. People with the positive attitude will tend to balance the relationship, help someone in need and offer to encourage the depressed people, so when they encounter difficulties, there will be always someone to help them. They care about the relationship with others and try their best to maintain the good relationship but they also pursuit the independence.

\section{(3) Group Level: the Relationship between People and Social Environment}

Social environment has a huge impact on people's psychology, which directly affects people's life experience and outlook on life and values. With the changing society and environment, many people can not adapt to the competitive society. Fierce competitions in modern society cause great pressure on people. People with positive emotions more could better adapt to environmental changes, and are willing to accept the challenge, won't be afraid or give up facing the competition. Those people are more likely to win in the competition, in return, they will get more positive emotions.

\section{The Importance of Applying Positive Psychology in the Ideological and Political Education of College Students}

Recognizing its important role, many colleges and universities have applied positive psychology into the ideological and political education of College students.

(1) Applying Positive Psychology into Ideological and Political Education of Colleges and Universities is to Implement the National Guidelines.

China has attached great importance to the ideological and political education of college students and published the related guidance documents of the application of positive psychology in higher education which point out that ideological and political education of college students should take the development level of modern society as the background and keep up with the paces of the times, respect students, take students as the center, not intervene in or limit the behaviors and thoughts of college students, cultivate students' innovative thinking and strive to cultivate college students to all-round talents. Making full use of positive psychology to educate college students helps students develop the habit of positive psychological, promotes the formation of positive emotion and personality, coordinate the relationship with others, guides the students to view life and social environment with positive attitude, improves their awareness of the progress and enhances their own competitiveness to better adapt to the social life in the future.

(2) Positive Psychology is Conducive to Carry out Ideological and Political Work Aiming at College Students' Psychological Characteristics.

College students are in the transitional period of adolescence with serious rebellious psychology, the immature idea, the inaccurate judgment and poor self-control, their inner worlds are more complex. In addiction, a growing number of college students boosts more pressure to the reading college students, so, the probability of contemporary college students with psychological problems is much higher than previous. Colleges and universities always pay attention to the psychological state and psychological change of college students, find out the potential problems or the problems 
that have already occurred timely and help students out of the psychological shadow. With the improving awareness, contemporary college students are like showing themselves better, want to be concerned and pursue a sense of existence. All these characteristics make contemporary college students no longer agree with the traditional education methods and contents, so universities should respect the psychological characteristics of students and make use of positive psychology to promote their positive emotions and increase their learning enthusiasm.

(3) The Application of Positive Psychology in Ideological and Political Work Could Help to Follow the Law of the Ideological and Moral Development of College Students.

Ideological and political character of college students is greatly influenced by the external environment, while the decisive factors are a series of psychological factors including the cognition, emotion, faith, will and behavior which are learned from the external environment, and they further develop all-around based on this. This process is a necessary way for all ideological contradictions to be transformed into positive thoughts, which reflects the level of cognition, emotion, faith, will and behavior a stairs type to rise. In this process, the lack of any link, will lead to stagnation of transformation of ideological contradictions, and ultimately lead to that college students could not form a healthy and positive ideological and moral.In terms of the ideological development of college students, the five processes of ideological transformation and their own efforts are are closely related. Therefore, to a certain extent, the positive psychological quality determines ideological and moral development of college students. Based on the mutual respect of students, the ideological and political education should fully explore and utilize psychological quality of educatee, further enhance the effect of ideological and political education

by students themselves. Positive psychology could better explore each student's ideological potential, help them improve self-confidence to realize their self value.

\section{The Ideological and Political Work in Colleges and Universities from the Perspective of Positive Psychology}

We should make effects and progress in all aspects in order to strength the actual effects and further promote development of ideological and political education work in colleges and universities. The author puts forward that application of positive psychology in ideological and political education in the university can better complete the work of ideological and political education in Colleges and universities.

(1) To Create a Positive Teaching Atmosphere and Stimulate Students' Learning Initiative and Creativity.

Positive psychology points out that psychology related with positive psychology could greatly improve the effect of ideological and political education of college students. In many developed countries, higher education institutions have offered positive psychology courses for students to choose. In fact, positive psychology courses, with the principle of "students oriented", can help college students a lot. So, the schools in China should learn from the experience of positive psychology education in foreign schools and offer such courses for the students to attend as soon as possible,in addition, make the best use of the classroom teaching space,apply the core ideas and techniques of positive psychology into the various disciplines in actual teaching process. Schools should also set up some simulation scenarios properly for students to practice to strengthen students' practical ability and stimulate learning interest, so their inner potential can be explored best.

(2) To Strengthen the Cultivation of Positive Personality of College Students.

Positive psychology points out that modern education should conform to the human standard, put forward the solution aiming at the problems in the real life to benefit more people. The idea of modern education is not just to solve the problems and contradictions in students' actual life. The ideological and political education in colleges and universities must take the positive education as the core. But in the actual education process, in most cases, the colleges focus on helping students to better solve the ideological problem instead of leading students to find a positive explanation of the problem, therefore, there is no comprehensive analysis of the fundamental causes of such 
problems, and they did not give students the opportunity to fully explore their own intrinsic potential.

Autonomy is the foundation of human existence, it is also the necessary thought of modern people living in modern society. Therefore, colleges should try to help students to creat independent personality from the aspects of thought and social contact independence. In addition, they also need to offer frustration education to students in order to cultivate their positive ,confident, optimistic and friendly characters. Psychology believes that in general, frustration can be divided into the following aspects:frustration scene,frustration cognition and frustration response, only these three aspects exist at the same time, mental frustration can be formed. Frustration education can teach students how to better deal with setback which is a part of life that everyone has to go through, so we can say the core of life actually is how to response it and move towards a new height after encountering the setback. And colleges should also teach students how to manage a harmonious and positive relationship.Environment interaction theory of psychological theory believes that everyone is an active individual in the society instead of accepting the surrounding environment with passive attitude, on the contrary, the individual is constantly learning and growing in the interaction with the environment. This means that in the process of ideological and political education in colleges and universities, the individual thought of college students will be combined with education, so the positive ideological and political characters will be produced.

(3) Ideological and Political Workers Should Pay Attention to the Cultivation of Positive Psychological Quality

$\mathrm{Hu}$ Jintao pointed out, we must comprehensively strengthen the teachers team construction in the ideological and political education work in colleges and universities, "especially through appropriate measures, in accordance with the relevant requirements, build high-quality, high level counselor teams, which can help teachers play a greater role in the process of ideological and political education of college students". On the other hand, we should learn to make use of the emotional factors in the process of the work. Relevant data show that the actual effect of the students to receive education is better based on a certain emotional between teachers and students. Actually, the process of education is the process of emotional interaction between teachers and students. In the process of ideological and political education of college students, teachers should learn to use emotion factors reasonably and provide more "love" for students in the process of education to make the emotional factors play a biggest role within the scope of rational education. From another perspective, the ideological and political education workers can make full use of the true, the good and the beautiful in the minds of students and try their best to fully mobilize the students' subjective initiative which can improve the effects of ideological and political education of college students.

(4) Using Positive Psychology Theory to Enhance the Teaching Effect of Ideological and Political Courses in Colleges and Universities.

The ideological and political education curriculum is one of the main ways to improve the students' ideological and political awareness. College ideological and political education workers should actively sum up experience in the actual teaching work, comprehensive use positive psychology, and strengthen the practical results of ideological and political education, try to build our country's ideological and political education curriculum into an excellent course that is accepted by the students. At the same time, they should pay attention to the emotional factors of students in the process of ideological and political education and make full use of the relevant theories of positive psychology to help students finish the relevant work.

\section{Conclusion}

The core of ideological and political education lies in moral education, while the core of psychology education lies in the soul education. On the surface, there is a big difference, but in essence, they are similar, they influence each other, learn from each other and benefit from each other. Positive psychology is a new discipline, it not only injects vitality into the psychology but also provides great help for the ideological and political education course, and comprehensively promote the 
ideological and political education work to keep pace with the times.

\section{Reference}

[1] Zhou Puyuan. Comments on William James's 'Mediating Term' in the Psychology of Religion [J]. Journal of Dalian University, 2010, 31 (5): 33-36

[2] Zhang Ying. Research on the Effectiveness of College Students' Ideological and Political Education in Positive Psychology Perspective [D]. Shaanxi University of Science and Technology, 2012

[3] Cui Yichen, Yin Jie. Interpreting Maslow's Hierarchy of Needs from Perspective of Ecological Psychology [J]. Journal of Beijing Forestry University (SOCIAL SCIENCE EDITION), 2013, 12 (3): 24-28

[4] Jiang Ying. Research on the inter-subjectivity of the Ideological and Political Education and Political Education under the View of the Psychology [J]. Theory Research, 2010, (28): 290291.

[5] Yang Zhiying, Realistic Value of Psychological Counseling on Ideological and Political Education in Colleges and Universities [J]. Leading Journal of Ideological \& Theoretical Education, 2009, (04): 54-58

[6] Li Zhongjun, Analysis of Acceptance Mechanism of College Students' Socialist Core Value System Education [J], Journal of Northeast Normal University (Philosophy and Social Sciences), 2009. (5): 87-90. 